\title{
Sex of the experimenter as a variable in the autokinetic illusion
}

\author{
JOHN L. ALLEN, SUSAN J. SIPES, and GREGORY P. SIPES \\ Spring Arbor College, Spring Arbor, Michigan 49283
}

\begin{abstract}
Twenty-two female undergraduate students were tested for agreement with an experimenter's suggested direction of movement in an autokinetic illusion experiment. Half of the subjects received the suggestion from a female experimenter and half from a male experimenter. Significantly more subjects responded affirmatively to the female experimenter's suggestion than to the male's $(p<.005)$.
\end{abstract}

In 1799, Von Humboldt, an astronomer, observed that when a stationary point of light is seen in the dark it appears to move, a phenomenon which Aubert, in 1887, named the autokinetic effect (Day, 1969). Since that time, considerable research has been conducted pertaining to this illusion, investigating such variables as target size (Luchins, 1954), suggestion (Dielman \& David, 1967; Pollis, Montgomery, \& Smith, 1975; Sherif, 1935), sex of subject (Elfner \& Page, 1963; Hamm \& Hoving, 1969), and degree of dark adaptation (White, 1973). Levy (1972) has summarized much of the research involving the autokinetic illusion. Little attention, however, has been given to a variable discussed by Kintz, Delprato, Mettee, Persons, and Schappe (1965), namely, the experimenter himself.

Fehrman and Hagel (Note 1), while conducting research on the effect of suggestion on direction of movement, found that all of their male subjects reported seeing autokinetic movement in the direction specified by the experimenters (both males), whereas none of the female subjects reported seeing such movement. During the first evening of testing, Beets and Whiting (Note 2) found that significantly more female subjects reported seeing movement in the specified direction when the suggestion was made by the female experimenter than when it was made by the male experimenter. However, no significant difference was found when additional subjects were tested 1 week later.

The present study is similar in most respects to the Beets and Whiting study, except that all subjects were tested within a 2-day period and admonished not to communicate with other subjects about the experiment.

\section{METHOD}

\section{Subjects}

The subjects were 22 female undergraduate students from a midwestern church-related college. They were randomly assigned

The authors wish to express their appreciation to M. Ray Denny for sponsoring and taking full editorial responsibility for this paper. Requests for reprints should be sent to John L. Allen, Psychology Department, Spring Arbor College, Spring Arbor, Michigan 49283. to two equal-sized groups, one being tested by a female experimenter and the other by a male experimenter.

\section{Apparatus}

The apparatus was located in a windowless, dark, sounddeadened room and was situated on a table $6 \mathrm{ft}(1.83 \mathrm{~m})$ in front of the subject. It consisted of a $15 \times 12 \times 9$ in. $(38.10 \times 30.48 \times$ $22.86 \mathrm{~cm}$ ) corrugated cardboard box painted flat black, with a 25-W bulb suspended in the center. All seams were taped, and the only visible light was emitted through a $1 / 32$-in. hole in a black metal plate attached to the front of the box. The hole was covered with tissue paper to diffuse the light. The light and a $120-\mathrm{V}$ 6-rpm motor, which emitted an audible hum to enhance the illusion, were operated by a common switch.

\section{Procedure}

The subjects were instructed to report for the experiment on either a Tuesday or Wednesday evening. All subjects who were being tested on a particular evening were seated together by both experimenters in a room across the hall from the testing room. The following taped instructions were presented, half recorded in the female experimenter's voice and half in the male experimenter's:

"This is an experiment in visual perception. We would like to find out to what extent people can perceive changes in a point of light without a visual framework. This lack of visual framework is the darkened room in which you will be tested. Please sit erect in the chair provided because this will give you the best view of the light.

"In order to perform this experiment it is necessary that you be dark adapted. Dark adaptation necessitates $1 / 2$ hour in the dark. During this adaptation period you will be listening to recorded music. At the end of the $1 / 2-h$ adaptation period you will be tested one at a time. When you are tested, we will turn on the apparatus and let you observe a point of light for approximately $1 \mathrm{~min}$. While observing the light, watch for movement and any changes in color or intensity. During this time we will question you about what you are seeing."

Following the instructions, the music was presented and the lights were turned out. The experimenters left the subjects alone during the adaptation period.

At the end of the dark-adaptation period, subjects were randomly assigned to either the male or female experimenter and guided to the sound-deadened room to be tested individually. When the subject was seated, the following taped instructions, half in the male and half in the female experimenter's voice, were presented:

"Remember, this experiment concerns visual perception. Sit erect in the chair. The point of light will be presented for approximately $1 \mathrm{~min}$. During this time, watch for movement and changes in color or intensity. I will question you about what you are seeing." 
The light and motor were turned on, and $10 \mathrm{sec}$ later the experimenter asked, "Is the light moving to the right?" After her response was noted, the subject was guided out of the testing room. All subjects were admonished not to discuss the experiment with anyone else for 2 days so as not to jeopardize the experiment. Those subjects who reported seeing the light move to the right were questioned as to whether they actually saw the light move or merely agreed because they thought the experimenter wanted them to see movement.

\section{RESULTS AND DISCUSSION}

A chi-square test revealed that perception of movement consonant with the experimenter's suggestion was dependent on which experimenter was giving the suggestion $\left(\chi^{2}=8.91, \mathrm{df}=1, \mathrm{p}<.005\right)$. Nine of the 11 subjects reported movement in the direction specified by the female experimenter, but only 2 of the 11 for the male. All subjects who reported seeing the light move to the right insisted that they actually saw the movement and did not just say so to please the experimenter. This latter finding supports the results obtained by Dielman and David (1967).

Although variables other than the sex of the experimenter may be involved, these results, taken in conjunction with those of Fehrman and Hagel (Note 1) and Beets and Whiting (Note 2), strongly suggest that the sex of the experimenter is an important factor. Further research is needed to determine if a similar effect is obtained with male subjects.

\section{REFERENCE NOTES}

1. Fehrman, P. G., \& Hagel, F. The effect of suggestion on horizontal movement in the autokinetic illusion. Unpublished manuscript, Judson College, 1969.
2. Beets, A., \& Whiting, M. The effect of the experimenter's sex on perception of suggested movement in the autokinetic illusion. Unpublished manuscript, Spring Arbor College, 1972.

\section{REFERENCES}

DAY, R. H. Human perception. New York: Wiley, 1969.

Dielman, T. E., \& DAvid, K. H. Temporal arrangement and specificity of set in an autokinetic situation. American Journal of Psychology, 1967, 80, 426-429.

Elfner, L. F., \& PAGE, H. A. Latency of the autokinetic effect as a function of pre-exposure. Perceptual and Motor Skills, 1963, 17, 862.

Hamm, N., \& Hoving, K. Age and sex differences in the perception of autokinesis in children. Perceptual and Motor Skills, 1969, 28, 317-318.

Kintz, B. L., Delprato, D. J., Mettee, D. R., Persons, C. E., \& Schappe, R. H. The experimenter effect. Psychological Bulletin, 1965, 63, 223-232.

LEVY, J. Autokinetic illusion: A systematic review of theories, measures, and independent variables. Psychological Bulletin, 1972, 78, 457-474.

Luchins, A. S. The relation of size of light to autokinetic effect. Journal of Psychology, 1954, 38, 439-452.

Pollis, N. P., Montgomery, R. L., \& Smith, T. G. Autokinetic paradigms: A reply to Alexander, Zucker and Brody. Sociometry, 1975, 38, 358-373.

ShERIF, M. A. A study of some social factors in perception. Archives of Psychology, 1935, 27, 1-60.

WhITE, R. C. Effect of prolonged dark adaptation on autokinetic movement. Perceptual and Motor Skills, 1973, 36, 521-522. 